\title{
The Promotion Effect of Knowledge Transformation on Psychological Intelligence: a New perspective of Political Identity
}

\author{
${ }^{12}$ Jian Deng*, ${ }^{12}$ Tongjian Zhang \\ ${ }^{1}$ School of Economics and Management, Leshan Normal \\ University \\ Sichuan Province, China \\ ${ }^{2}$ Jiangsu University, \\ Zhenjiang 212013, China
}

\author{
Ren $\mathrm{He}$ \\ Chengdu Modern Agriculture Financing guarantee Co.Ltd \\ Chengdu, China
}

\begin{abstract}
In knowledge economy, knowledge-based talents are an important capital of the state-owned enterprises and national economy. Political identity of knowledge-based talents lays an important impact on knowledge ability development, but the research from this perspective is relatively scant. Our study theoretically sets up a model for political identity, knowledge transformation and psychological intelligence, and tests the micro-mechanism of the impact of political identity on the knowledge-based talents with the samples from the China's state-owned enterprises. The study finds that political identity of knowledge-based talents not only has social value, but also promotes knowledge transformation and develops psychological intelligence. This paper puts forward some strategies for cultivating psychological intelligence of the knowledge-based talents in the end. All in all, this paper develops the theoretical and practical value of political identity research and raises guidance and incentive reference to the political identity of knowledge-based talents for the state-owned enterprises.
\end{abstract}

Keywords-political identity; knowledge transfer; dimensional intelligence theory; psychological intelligence

\section{INTRODUCTION}

"One has a less than a hundred-year life, but a thousand years' concern." That is the typical style of Chinese ancient intellectuals and a portrayal of modern Chinese intellectuals. The intellectual is a leading force of a country or a nation. It delivers the most innovative, revolutionary, and forward-looking spirits, and exerts a direct, far-reaching, and fundamental impact on a country or nation. Knowledge-based talents are representatives of the intellectuals. They are the talents equipped with great knowledge, and can use their knowledge to carry out various work and promote sustainability of a society. There are a large number of the knowledge-based talents in universities, hospitals, professional research institutions, research and development institutions in large enterprises, and high-tech private enterprises.

The exploration of the knowledge-based talents is one of the dynamic mechanisms for social development in the era of knowledge economy, and it is the core force for promoting political, economic and cultural changes. The existing knowledge-based talents exploration research is biased, as it regards the knowledge-based talent exploration mechanism as a "black box". Only knowledge time, career planning, psychological contract, training investment, leadership behavior and other aspects are used to study the knowledge-based talents. The influence of values in modern economic society is ignored.

The existing research on the exploration of the knowledge-based talents is still stuck in the classical economics research framework and sticks to the analysis of "rational economic people", and takes the knowledge-based talents as a living body who maximizes self-utility and ignores their social preference, which is a sever departure from social reality and even a misinterpretation of the knowledge-based talents [1]. In fact, the knowledge-based talents not only care about their own interests, but also the others, and pay attention to the living conditions of the others individual, groups and the public. Thus, it largely breaks away from the bondage of " rational economic people preference" of Adam Smith [2].

Among the social preferences of the knowledge-based talents, political identity is a core one. If the knowledge-based talents agree with the values of the environment in which they live, they may be more creative. On the contrary, if the knowledge-based talents contradict those values, they will be passive, evasive, and decadent [3]. In the early days of the founding of the People's Republic of China, Qian Xuesen returned to China without hesitation and made outstanding contributions to the Atomic Bombing Invention, which was most likely due to the admiration of the values of New China.

The development of behavioral economics challenges and shakes the foundation of the traditional economic theory, and points out the direction for the knowledge-based talents exploration research. It regards the knowledge-based talents as a living person of active, flesh and bloody, emotional [4]. Education, training, vocational training, etc. are the platforms for the knowledge-based talents development, but not the elements of incentive. The elements are the values, which are playing the increasingly role in modern society and stimulate the creativity of the knowledge-based talents. 
The rise of Knowledge Management Theory has developed the research on the knowledge-based talentsexploration mechanism. It breaks the "black box", and analyzes the internal mechanism of knowledge-based human capital exploration [5].Knowledge management is an important field in management. It uses a large number of research methods and has accumulated a large number of research findings. Those methods and findings can be completely transplanted into the knowledge-based talentsexploration research. According to Anne Brooking, human capital is one of the elements of intellectual capital, which consists of human capital, structural capital, market capital, and customer capital. Among them, structural capital refers to the inherent good quality in organizational processes, mechanisms and culture, and is largely influenced by human capital [6].

For a long time, the knowledge-based talents creativity has been seen as an abstract ability, expressed in organizational performance. However, from the perspective of psychology, the creativity of the knowledge-based talents is a kind of psychological intelligence. The intellectual theory in psychology provides theoretical support for the analysis of the micro-mechanism of knowledge-based talent creativity. It can be seen that, based on the perspective of political identity, with the help of the methods and findings on knowledge management theory and on the platform of intellectual decomposition, we can deeply reveal the mechanism of the cultivation of knowledge-based talent creativity, and thus discover more effective strategies and measures for exploringknowledge-based talents.

The contributions of this paper are followings: this paper studies the positive effect of political identity of knowledge-based talents on psychological intelligence from the perspective of knowledge transformation, that is, knowledge socialization, knowledge externalization, knowledge internalization and knowledge combination, and comes forward some specific guiding strategies for political identity of the knowledge-based talents. This paper will further develop the study on political identity of the knowledge-based talents and promote the progress of cultivating practice of political identity of the knowledge-based talents.

The arrangements of the paper are followings: the second part of this paper summarizes the theoretical relationship among political identity, knowledge transformation and psychological intelligence, and shed some light on the idea of research model. The third part structures a model for the above three elements after a theoretical interpretation. The fourth part is the test based on the sample data of knowledge-based talents in China's state-owned enterprises and the structural equation model. The fifth part puts forward some cultivation strategies for psychological intelligence of the knowledge-based talents from the perspective of political identity.

The paper is structured as follows. Section 2 discussed related literatures. Theoretical model and hypotheses are proposed in section 3. Section 4 conducts reliabity analysis, factor analysis and structure equation model. Conclusion is put forward in section 5 .

\section{LITERATURE REVIEWS}

\section{A. Political Identity Analysis}

Political identity refers to a stable political consciousness or an emotion felt by people in the political field, political activities and political life [7]. Generally speaking, in modern society, people always establish their own identities in their social relations. They regard themselves as a member in a political organization, or a member of a group anda stratum, or a participant of a political event, a political behavior anda politic process, or a pursuer of certain political beliefs, political beliefs, and political ideals, consciously regulate their political behavior with Party groups or political missions [8]. It can be seen that political identity refers to the unanimity of their identity or similarity with a certain kind of politics. In essence, it is people's trust and belief in the political system, the basis of political domination, and the internal force that unites the members of society.

Knowledge-based talents are the most sensitive and active group in China's development. They can independently experience and judge the changes in the current political situation, and show their attitudes in words and deeds. Thus, the political identity of the knowledge-based talents can be divided into two elements: emotional political identity and behavioral political identity. The former refers to the attitude identity with the political system in emotion and feelings, and the latter refers to the behavior identity with the political system in work and life.

\section{B. Knowledge Transformation Analysis}

In 1995, Nonaka, a Japanese scholar, put forward the SECI knowledge transformation model. He believed that inexplicit knowledge and explicit knowledge could transform and interact with each other during enterprise management or technological innovation, andbring knowledge creation [10]. Nonaka believes that there are four modes of knowledge transformation: knowledge socialization, knowledge externalization, knowledge combination and knowledge internalization. If the form of knowledge changes from inexplicit state to implicit state, it is called knowledge socialization. If the knowledge form transforms from implicit knowledge to explicit knowledge, it is called knowledge externalization. If the knowledge form transforms from explicit knowledge to explicit knowledge, it is called knowledge combination[11].If knowledge from transforms from explicit knowledge to implicit knowledge, it is called knowledge implicitization. Explicit knowledge refers to the knowledge that can be transmitted in a standardized and systematic language and which can be expressed in text. Implicit knowledge refers to knowledge that exists in the form of belief, metaphor, intuition, knack, mode of thinking, organizational culture, etc. It is difficult to express it in clear language and words.

In modern economy, implicit knowledge is a subject knowledge. Lots of valuable knowledge exists in the form of implicit knowledge, while the value of explicit knowledge is low and its weight is small. It is called "the corner of the iceberg" in knowledge capital system. It is estimated that implicit knowledge accounts for more than $80 \%$ of total knowledge capital[12]. 
In the course of knowledge research, the SECI model is a milestone achievement, which opens up a new field in knowledge research and is applied to many research areas in knowledge management. Similarly, for the knowledge-based talents, knowledge transformation can still be divided into four forms: socialization, externalization, combination and internalization.

\section{Psychological Intelligence Analysis}

In 1985, Professor Sternberg, a famous American psychologist, elaborated on the connotation of his theory of "triarchic theory of intelligence" in his book Beyond Intelligence. $\mathrm{He}$ believes that individual intelligence is essentially a psychological activity of adaptation, coordination, selection and transformation of the real environment [13].

The triarchic theory of intelligence includes three elements: componential sub-theory, experiential sub-theory and contextual sub-theory. Sternberg's theory of intelligence has a great impact on psychology and is a milestone of psychological intelligence theory. He emphasized that a complete theory of intelligence must include three aspects: the internal component of intelligence, the external function of intelligence component, and the internal relationship between intelligence component and experience. The internal component of intelligence constitutes component intelligence, the external function of intelligence component constitutes empirical intelligence, and the relationship between intelligence component and experience constitutes situational intelligence.

\section{Practical Value}

The value and role of political identity of the knowledge-based talents have aroused wide attention. Zhang and Yang (2014) argue that the political identity of the knowledge-based talents can not only optimize psychological contract, but also enhance successful intelligence, thereby improve the social value of the knowledge-based talents [15]. The Wuhan Socialist College (2017) believes that the Party and the government should attach importance to properly guiding the political identity of the knowledge-based talents, so as to further activate and explore the potentials of the knowledge-based talents and better serve the society. Pan and Ren(2018) believe that the political identity of the knowledge-based talents determines the extent of their ability to play, and the higher the political identity, the better the ability.

However, from the perspective of political identity, the existing research, on the one hand, does not look into the micro-mechanism of knowledge ability realization of the knowledge-based talents; on the other hand, the existing researchdoes not uncover the essentials of the knowledge ability of the knowledge-based talents. In view of this, by borrowing the findings on political identity of the knowledge-based talents and the theories of knowledge transformation and psychological intelligence, this paperstudiesthe effect of political identity on knowledge transformation and then on psychological intelligence, andthen forms a correlation model for political identity, knowledge transformation and psychological intelligence, and studies the micro-economic effect of political identity of the knowledge-based talents.

\section{THEORETICAL MODEL AND HYPOTHESES}

\section{A. Hypothesis Development}

1) The Promotion Effect of Emotional Political Identity on Knowledge Transformation

Emotional political identity means the identity unanimity of the knowledge-based talents with the current social system, governing mode and interest trend, which will inevitably have an impact on their own perception, emotion and thinking mode. If the intellectuals have a positive attitude towards the political system, they will feel happy, excited and exulted and actively devote themselves to various social undertakings [15]. In the mood of emotional identity, the knowledge-based talents are willing to contribute and share their skills, know-how and experience with others or teams. They may also be curious about social phenomena and professional knowledge, actively explore and dig, and raise their thinking to a new level. At the same time, in the mood of emotional identity, the knowledge-based talents will also strengthen communications with colleagues, friends and family, constantly come up with new ideas and concepts, and carry out in-depth thinking in the professional field, so as to reach the peak of their professional understanding[16]. On the contrary, if the knowledge-based talents don't quite agree with the political model of their lives emotionally, they may feel bothered, hesitant and depressed, and hesitate, which inevitably hindering their explicit and implicit knowledge activities and holding back the realization of knowledge transformation.

Based on the above analysis, the following research hypotheses can be proposed:

H1a: Emotional political identity of the knowledge-based talents helps to promote the progress of knowledge externalization

H1b: Emotional political identity of the knowledge-based talents helps promote the progress of knowledge internalization

H1c: Emotional political identity of the knowledge-based talents helps to promote the progress of knowledge integration

H1d: Emotional political identity of the knowledge-based talents helps to promote the progress of knowledge socialization

\section{2) The Promotion Effect of Behavioral Political Identity} on Knowledge Transformation

Behavioral political identity means that the knowledge-based talents show their identity with the political system in their behavior. If the knowledge-based talents agree with the certain political system, they will never stay in ideology, but will actively participate in the process of political implementation, actively promote political ideas, participate in political gatherings, and maintain political interests. Human behavior is mutually influential and united, and the behavioral identity to the political system is bound to facilitate the development and enhancing other behaviors[17]. Under the behavioral political identity model, the knowledge-based talents have a deeper understanding of society and in a broader vision, which will promote various knowledge activities because of the changes in thinking patterns. To reveal and discover a deeper application mechanism, under behavioral 
political identity, the knowledge-based talents will find the best way to present their skills and know-how to teams and the others, to compact their own ideas, and to observe and examine the world with deeper eyes. At the same time, the knowledge-based talents will also carry out career planning in a grand space, integrate all kinds of knowledge into one, combine into a more valuable knowledge system, and explore their mental potential with a highly innovative mindset to achieve union of mind and soul. [18]. On the contrary, if the knowledge-based talents do not agree with the political model, they will be anxious, extreme, and embarrassed, cynical, self-destructive, and keep their own explicit and implicit knowledge activities, which is not conducive to knowledge and the realization of transformation [19].

Based on the above analysis, the following research hypotheses can be proposed:

H2a: The political identity of the knowledge-based talents helps to promote the progress of knowledge externalization

$\mathrm{H} 2 \mathrm{~b}$ : The political identity of the knowledge-based talents helps to promote the progress of knowledge internalization

H2c: The political identity of the knowledge-based talents helps to promote the progress of knowledge integration

$\mathrm{H} 2 \mathrm{~d}$ : The political identity of the knowledge-based talents helps to promote the progress of knowledge socialization

3) The Promotion Effect of Knowledge Transformation on Psychological Intelligence

Knowledge transformation is the knowledge behavior of knowledge-based talents, which is integrated into various activities, thus enriching the experience of the knowledge-based talents, expanding the eyes of knowledge-based talents, and improving the skills of the knowledge-based talents, which will promote the growth of mental and intellectual intelligence of the knowledge-based talents. The triarchic theory of intelligence emphasizes the relationships among intelligence and environment, experience, factors and procedures. It believes that intelligence is the objective adaptation, selection and transformation of the subject. It is inextricably related to knowledge transformation. Specifically: the knowledge externalization enhances the understanding the environment and compacts the strategic vision of knowledge-based talents [20]; the knowledge internalization allows the knowledge-based talents to have a deeper understanding of the internal mechanisms of things, and strengthen their analytical capabilities and improve more judgmental ability; knowledge integration can enable the knowledge-based talents to place themselves in a more ambitious environment, build high-rise, control the overall situation of things more effectively, coordinate the cooperation relationship between the parties, and lay the foundation for the sublimation of thinking for a higher starting point; knowledge socialization can get the thinking endurance of the knowledge-based talents further practiced and improved, optimize the thinking model, and increase the intensity of thinking. It can be seen that the four elements of knowledge transformation promote the psychological intelligence in an all-round way, especially the knowledge socialization and the knowledge implicitness are more persistent.

Based on the above analysis, the following research hypotheses can be proposed:

H3a: Knowledge externalization helps promote the talents' psychology Intelligence

H3b: Knowledge internalization helps promote the talents' psychology Intelligence

H3c: Knowledge Integration helps promote the talents' psychology Intelligence

H3d: Knowledge Socialization helps promote the talents' psychology Intelligence

\section{B. Research Model}

This study intends to use Structural Equation Model to test the above hypothesis. Structural equation models can be used for model test and model comparison, as well as for model evaluation and model correction. Researchers generally start with a pre-set initial model, then test the model and data. If the initial model and the sample data are not well fitted, then the initial model will be corrected, and then test. It repeats until the model fits well with data and reasonable parameter estimates is obtained. Based on research hypotheses and factor decomposition, a research model can be constructed as shown in Figure 1. 


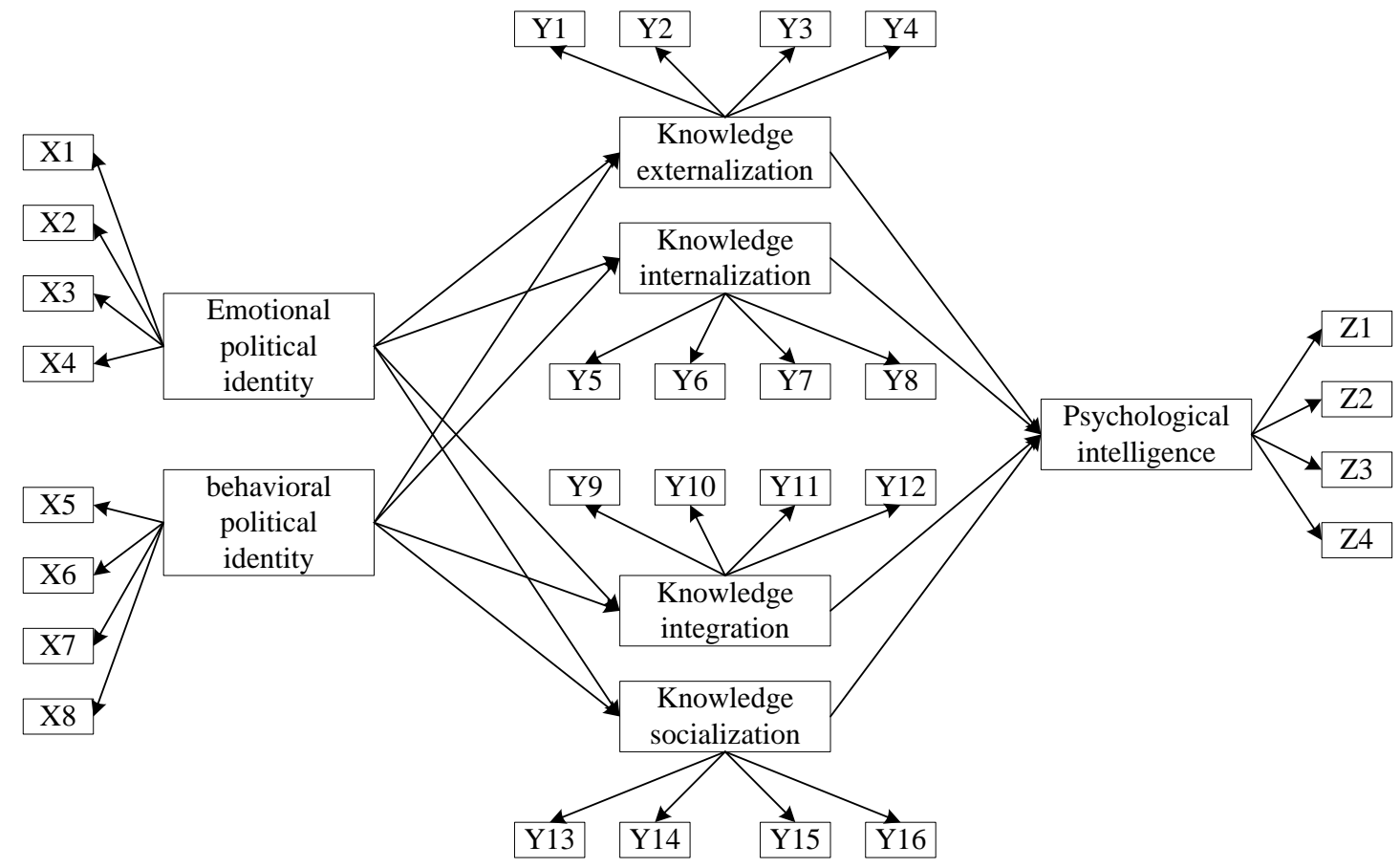

Fig. 1 Research model

\section{RESULTS AND DISCUSSIONS}

\section{A. Measurements}

\section{1) Measurements Decomposition of Political Identity}

According to political identity theory and related research findings, it is possible to decompose the elements of emotional political identity and behavioral political identity of knowledge-based talents.

Emotional political identity elements are decomposed into four indicators: (1) agree with the political system of the society; (2)agree with the ruling party's ruling style; (3)agree with the values advocated by the ruling party; (4)think that the ruling party and members do not specialinterests.

The elements of behavioral political identity are decomposed into four indicators: (1)actively participate in the political activities of the ruling party; (2)actively promote the program, spirit and concept of the ruling party; (3) strictly regulate the behavior of the ruling party's system and rules; (4) resist and counterattack the words and deeds of the ruling party.

\section{2) Measurements Decomposition of Knowledge}

\section{Transformation}

There are a lot of research on elements decomposition of knowledge transformation, and there are different decomposition forms in different management situations. For the knowledge-based talents, it needs to be guided by the improvement of individual knowledge systems.

The knowledge externalization are decomposed into four indicators: (1) be willing to summarize their own experience and transmit to others; (2) be good at writing and expressing their own thinking patterns and potential skills; (3) be good at choosing ways to express subconscious; (4) be effective at the choice of transmission objects with high savvy, good at learning, and open-mindedness.

The knowledge internalization is decomposed into four indicators: (1)have a keen observation of new things appearing in work and life; (2) be good at engaging in the surface phenomenon of the object to sum up the inner law; (3) effectively receive, digest and use others The knowledge imparted; (4) be good at seeing the essence through the phenomenon of things.

The knowledge integration is decomposed into four indicators: (1)actively participate in various academic activities and academic exchanges; (2)view the knowledge system of the subject from a global perspective; (3) be good at combining traditional knowledge into new knowledge; (4) quickly and effectively find ways to combine knowledge.

The knowledge socialization is decomposed into four indicators: (1) be good at deep thinking to discover the inner rules of things; (2) be good at comprehending others' shackles, experiences and skills; (3)constantly surpasstheir own mental models to reach a new realm; (4) be good at absorb the essence of the organization or team culture to improve your way of thinking.

3) Measurements decomposition of Psychological Intelligence

The triarchic theory of intelligence is an intellectual theory that emphasizes the importance of cognition in the process of problem solving. It focuses on the operational procedures, functions, the relationship between intelligence and the environment, and the relationship between intelligence and 
constituent elements. The theory of inner workings of intelligence that produces intelligence [13].

Based on the triarchic theory of intelligence and related research results, the psychological intelligence elements of the knowledge-based talents are decomposed into four indicators: (1) be good at using existing experience to solve new problems; (2) be good at thinking about the same problem from different perspectives; (3) be good at adapting to different working environments, living environments and cultural environments; (4) be good at deep thinking about abstract problems.

\section{B. Respondents}

This study collected data from the knowledge-based talents in various industries in China viaLikert 7-point scale. According to factor decomposition and referring to the expression of relevant historical scales, the measure items of political identity, knowledge transformation and psychological intelligence are designed respectively $(8,16$ and 4 items).Before conducting the survey, weexplain the purpose and intention of the survey to the respondents briefly in order to get the maximum cooperation from the respondents. The sample survey began on December 1, 2017 and ended on February 2, 2018, covering a span of 64 days. A total of 200 valid samples were obtained, 7 times the number of indicators, which meets the data requirements of structural equation model test. The sample features are shown in table 1.

TABLE I SAMPLE CHARACTERISTICS

\begin{tabular}{|c|c|c|c|c|c|c|c|}
\hline Feature & Category & $\begin{array}{l}\text { Number of } \\
\text { samples }\end{array}$ & Proportion & Feature & Category & $\begin{array}{l}\text { Number of } \\
\text { samples }\end{array}$ & Proportion \\
\hline \multirow{2}{*}{ Gender } & male & 146 & 73 & \multirow{4}{*}{ The title } & $\begin{array}{l}\text { Senior Title of } \\
\text { Professional }\end{array}$ & 40 & 20 \\
\hline & female & 54 & 27 & & Intermediate Title & 74 & 37 \\
\hline \multirow{13}{*}{$\begin{array}{l}\text { Industry } \\
\text { distribution }\end{array}$} & metallurgical & 18 & 9 & & Primary Title & 68 & 34 \\
\hline & energy & 22 & 11 & & No title & 18 & 9 \\
\hline & transport & 10 & 5 & \multirow{4}{*}{$\begin{array}{l}\text { Education } \\
\text { background }\end{array}$} & Doctor & 60 & 30 \\
\hline & medicine & 12 & 6 & & Master & 80 & 40 \\
\hline & financial & 6 & 3 & & Bachelor Degree & 40 & 20 \\
\hline & $\begin{array}{l}\text { Commerce and } \\
\text { trade }\end{array}$ & 4 & 2 & & $\begin{array}{l}\text { Junior College and } \\
\text { Below }\end{array}$ & 20 & 10 \\
\hline & education & 8 & 4 & \multirow{7}{*}{$\begin{array}{l}\text { Length } \\
\text { service }\end{array}$} & $<5$ & 20 & 10 \\
\hline & biological & 18 & 9 & & $5 \sim 10$ & 24 & 12 \\
\hline & chemical & 22 & 11 & & $11 \sim 15$ & 40 & 20 \\
\hline & electronic & 34 & 17 & & $16 \sim 20$ & 42 & 21 \\
\hline & geological & 16 & 8 & & $21 \sim 25$ & 34 & 17 \\
\hline & mining & 14 & 7 & & $26 \sim 30$ & 20 & 10 \\
\hline & agricultural & 16 & 8 & & $>30$ & 20 & 10 \\
\hline \multirow{7}{*}{ Age distribution } & $<30$ & 18 & 9 & \multirow{3}{*}{ Position } & $\begin{array}{l}\text { Division Level and } \\
\text { Above }\end{array}$ & 28 & 14 \\
\hline & $31 \sim 35$ & 30 & 15 & & Level & 36 & 18 \\
\hline & $36 \sim 40$ & 36 & 18 & & The Masses & 136 & 68 \\
\hline & $41 \sim 45$ & 42 & 21 & \multirow{7}{*}{ Professional } & $\begin{array}{l}\text { Science and } \\
\text { Engineering }\end{array}$ & 70 & 35 \\
\hline & $46 \sim 50$ & 32 & 16 & & Agriculture & 16 & 8 \\
\hline & $50 \sim 55$ & 24 & 12 & & Medical Science & 36 & 18 \\
\hline & $>55$ & 18 & 9 & & Philosophy & 24 & 12 \\
\hline \multirow{3}{*}{$\begin{array}{l}\text { Political } \\
\text { background }\end{array}$} & $\begin{array}{l}\text { The member of } \\
\text { Communist Party } \\
\text { of China }\end{array}$ & 78 & 39 & & Law and Politics & 16 & 8 \\
\hline & $\begin{array}{l}\text { The Democratic } \\
\text { Parties }\end{array}$ & 40 & 20 & & $\begin{array}{ll}\text { Economics and } \\
\text { Management }\end{array}$ & 28 & 14 \\
\hline & Nonpartisan & 82 & 41 & & Else & 10 & 5 \\
\hline
\end{tabular}




\section{Reliability and Validity Test}

The reliability test and validity test can be achieved by factor analysis. Factor analysis includes exploratory factor analysis and validation factor analysis, the former can be based on data, to discover the common factors among questions, and the latter is from the theory and tests the impact of the common factors among questions. In implementation of the test, both two category factors can be analyzed and used. First, we will do exploratory factor analysis, and then do validation factor analysis.

\section{1) Reliability test}

Based on 200 valid sample data, using SPSS18.0 software, through exploratory factor analysis, the reliability test can be achieved. The results are shown in Table 2. It can be seen that the various measurement tables designed by this research have good reliability.

TABLE II RESULTS OF RELIABILITY TEST

\begin{tabular}{|c|c|c|c|c|c|}
\hline Elements & $\begin{array}{l}\text { Factor load } \\
\text { Maximum }\end{array}$ & Factor load Min & $\begin{array}{l}\text { Corrected } \\
\text { Item-TotalCorrelation } \\
\text { Min }\end{array}$ & Cronbachionlue & $\begin{array}{l}\text { Cumulative amount of } \\
\text { interpretation }\end{array}$ \\
\hline Emotional political identity & 0.811 & 0.365 & 0.53 & 0.7929 & $79 \%$ \\
\hline Behavioral political identity & 0.729 & 0.300 & 0.50 & 0.7559 & $58 \%$ \\
\hline Knowledge Externalization & 0.709 & 0.289 & 0.55 & 0.8760 & $52 \%$ \\
\hline $\begin{array}{l}\text { Knowledge } \\
\text { Internalization }\end{array}$ & 0.723 & 0.342 & 0.58 & 0.7287 & $42 \%$ \\
\hline Knowledge Integration & 0.689 & 0.300 & 0.61 & 0.7545 & $47 \%$ \\
\hline Knowledge Socialization & 0.675 & 0.332 & 0.66 & 0.7332 & $51 \%$ \\
\hline Psychological Intelligence & 0.611 & 0.287 & 0.52 & 0.8098 & $44 \%$ \\
\hline
\end{tabular}

\section{2) Validity test}

Based on 200 valid sample data and using SPSS18.0 software and LISREL 8.7 software, the validity test of can be achieved by factor analysis. The test results are shown in Table 3 . It can be seen that the various measurement tables designed by this research have good validity.

TABLE III RESULTS OF VALIDITY TEST

\begin{tabular}{|c|c|c|c|c|c|c|}
\hline Gauge name & $\chi^{2} / d . f$ & RESEA & $\begin{array}{l}\text { Factor } \\
\text { Maximum }\end{array}$ & load & Factor load Min & Minimum T value \\
\hline Emotional political identity & 1.22 & 0.033 & 0.71 & & 0.40 & 3.99 \\
\hline Behavioral political identity & 0.87 & 0.029 & 0.66 & & 0.29 & 6.87 \\
\hline Knowledge Externalization & 1.43 & 0.033 & 0.78 & & 0.28 & 2.45 \\
\hline Knowledge Internalization & 2.00 & 0.017 & 0.70 & & 0.26 & 7.98 \\
\hline Knowledge Integration & 2.16 & 0.020 & 0.69 & & 0.30 & 6.20 \\
\hline Knowledge Socialization & 0.97 & 0.054 & 0.77 & & 0.45 & 5.54 \\
\hline Psychological Intelligence & 1.08 & 0.014 & 0.54 & & 0.25 & 3.18 \\
\hline
\end{tabular}

D. Model Test

After the reliability test and validity test, a full model test can be performed. In this study, the full model test was performed. The matrix is shown in Table 4.

TABLE IV HYPOTHESES TESTING

\begin{tabular}{|c|c|c|c|c|c|c|}
\hline \multicolumn{2}{|c|}{ Exogenous variables } & \multirow{2}{*}{$\begin{array}{l}\text { Endogenous variable } \\
\text { Knowledge } \\
\text { Externalization }\end{array}$} & \multirow{2}{*}{$\begin{array}{l}\text { Path hypothesis } \\
\text { Assume H1a }\end{array}$} & \multirow{2}{*}{$\begin{array}{l}\begin{array}{l}\text { Coefficient } \\
\text { load }\end{array} \\
0.44\end{array}$} & \multirow{2}{*}{$\begin{array}{l}\text { Standard error } \\
\text { se }\end{array}$} & \multirow{2}{*}{$\frac{\mathrm{T} \text { value }}{4.00}$} \\
\hline $\begin{array}{l}\text { Emotional } \\
\text { identity }\end{array}$ & political & & & & & \\
\hline $\begin{array}{l}\text { Emotional } \\
\text { identity }\end{array}$ & political & $\begin{array}{l}\text { Knowledge } \\
\text { Internalization }\end{array}$ & AssumeH1b & 0.19 & 0.10 & 1.90 \\
\hline $\begin{array}{l}\text { Emotional } \\
\text { identity }\end{array}$ & political & $\begin{array}{l}\text { Knowledge } \\
\text { Combination }\end{array}$ & AssumeH1c & 0.46 & 0.12 & 3.89 \\
\hline $\begin{array}{l}\text { Emotional } \\
\text { identity }\end{array}$ & political & $\begin{array}{l}\text { Knowledge } \\
\text { Socialization }\end{array}$ & AssumeH1d & 0.33 & 0.10 & 3.30 \\
\hline
\end{tabular}


Table IV, cont

\begin{tabular}{lllllll}
$\begin{array}{l}\text { Behavioral } \\
\text { identity }\end{array}$ & political & $\begin{array}{l}\text { Knowledge } \\
\text { Externalization }\end{array}$ & AssumeH2a & 0.45 & 0.12 & 3.75 \\
$\begin{array}{l}\text { Behavioral } \\
\text { identity }\end{array}$ & political & $\begin{array}{l}\text { Knowledge } \\
\text { Internalization }\end{array}$ & AssumeH2b & 0.50 & 0.12 & 4.12 \\
$\begin{array}{l}\text { Behavioral } \\
\text { identity }\end{array}$ & political & Knowledge Integration & AssumeH2c & 0.14 & 0.10 & 1.40 \\
$\begin{array}{l}\text { Behavioral } \\
\text { identity }\end{array}$ & political & $\begin{array}{l}\text { Knowledge } \\
\text { Socialization }\end{array}$ & AssumeH2d & 0.28 & 0.09 & 3.09 \\
$\begin{array}{l}\text { Knowledge } \\
\begin{array}{l}\text { Externalization } \\
\text { Knowledge }\end{array}\end{array}$ & $\begin{array}{l}\text { Psychological } \\
\text { intelligence }\end{array}$ & AssumeH3a & 0.35 & 0.10 & 3.50 \\
$\begin{array}{l}\text { Internalization } \\
\text { Psychological } \\
\text { intelligence }\end{array}$ & AssumeH3b & 0.45 & 0.13 & 3.46 \\
$\begin{array}{l}\text { Knowledge Integration } \\
\text { Psychological }\end{array}$ & $\begin{array}{l}\text { intelligence } \\
\text { Knowledge }\end{array}$ & $\begin{array}{l}\text { Psychological } \\
\text { intelligence }\end{array}$ & AssumeH3c & 0.38 & 0.13 & 2.95 \\
\hline socialization & AssumeH3d & 0.45 & 0.15 & 3.00
\end{tabular}

According to Table 4, H1b and $\mathrm{H} 2 \mathrm{c}$ did not pass the test, while the remaining assumptions passed the test. The list of list, all the fit indicators are within the optimal value range, fitted indices for the model is shown in Table 5. In the fit index indicating that the test effect of the model is good, no further model adjustment is required.

TABLE V MODEL FITNESS INDICES

\begin{tabular}{llllllllll}
\hline Fit indicator & X2/d.f & RMSEA & RMR & CFI & NFI & IFI & GFI & TLI & AGFI \\
\hline Fit results & 1.933 & 0.027 & 0.046 & 0.911 & 0.989 & 0.902 & 0.976 & 0.943 & 0.888 \\
\hline Optimal value trends & $<3$ & $<0.08$ & $<0.1$ & $>0.9$ & $>0.9$ & $>0.9$ & $>0.9$ & $>0.9$ & $>0.8$ \\
\hline
\end{tabular}

\section{CONCLUSIONS}

This paper constructs a model for political identity, knowledge transformation and psychological intelligence of the knowledge-based talents, which enriches the political identity theory of the knowledge-based talents. In addition, this paper reveals the internal mechanism of political identity effect via the structural equation model test and extends the political identity research to the micro level, which contributes to the political identity guidance of the knowledge-based talents.

According to our findings, from the macro level, the political identity of the knowledge-based talents promotes knowledge transformation, and thus promotes the growth of psychological intelligence. Emotional political identity and behavioral political identity play a role in promoting knowledge transformation as a whole, and become the driving force for psychological intelligence growth. It can be seen that in the era of knowledge economy, the exploration of knowledge-based human capital should not ignore the influence of political consciousness or political idea, but need to attach great importance to their long-term effects, which is an important channel for cultivating the creativity of the knowledge-based talents. Relevant institutions and individuals should clearly aware that the knowledge-based talents are emotionally rich economic individuals, not walking dead men who can be easily tempted by materials, but those who have their own political mind and have a crucial impact on the results of their capabilities.

From the micro level, (1) The emotional and political identity of the knowledge-based talents effectively promotes the growth of knowledge externalization, knowledge integration and knowledge socialization, but lacks the promotion of the knowledge internalization;(2)The behavioral political identity of the knowledge-based talents effectively promotes the growth of knowledge externalization, knowledge internalization and knowledge socialization, and lacks the promotion of the growth of knowledge integration. (3) Under the premise of political identity, the four forms of knowledge transformation have a driving effect on the growth of psychological intelligence. It can be seen that there is some room for promoting knowledge transformation by emotional political identity and behavioral political identity.

For a long time, the exploration of china's knowledge-based human capital has failed to make a substantial breakthrough, which holds back the realization of the national innovation technology strategy. Despite some so called "great" researches, the real effect of them is not ideal. In China's various industries, technological innovation capacity is still low, and mainly depends on extensive expansion, rather than intensive production, so it is difficult to have sustainable competitiveness. According to the results and the practical understanding of the knowledge-based talents in China, it can be concluded that, in theory and practice, the cultivation of the psychological intelligence of the knowledge-based talents should be changed or improved from the following perspectives:

Expand the discipline of the knowledge-based talents research. It cannot be just stuckin management discipline. There is no doubt that the creativity of the knowledge-based talents is influenced by their world views, values and outlook on life. It is unreasonable to ignore this reality. On many occasions, human potential cannot be measured by scale. At the same time, creativity is a kind of psychological ability. Therefore, at the micro level, we should seek solutions from psychological behaviors. If the study of creativity is still stuck 
in the input-output model, it will be doomed to get nothing. It can be seen that the theoretical basis of the exploration of the knowledge-based talents is a synthesis of political science, management, sociology and psychology.

Enhance the understanding of the human nature of knowledge-based talents and scientifically understand the demand level of the knowledge talents. Among the knowledge-based talents research in China, few involves the discussion of the human nature needs of knowledge talents, but directly studies the path of creativity, which concentrates on details but forget the main purpose or objective. If a fuzzy judgment on human nature, it is impossible to discuss the behavior. In fact, in the relevant research, there is a lot of distortion of the human needs of knowledge-based talents, from the extreme of complete altruism to the extreme of complete self-interest. Political identity contains the essence of self-interest and altruism, which is more in line with the diversified human nature of the knowledge-based talents and more closely related to the psychological characteristics of knowledge-based talents.

The political identity guidance is an effective way to cultivate the knowledge-based talents and should be paid close attention. Before the reform and opening up, the incentives for the knowledge-based talents solely depended on political indoctrination. After the reform and opening up, the incentives completely rejected political factors. Both the above are so extreme and wrong. In modern society, it is inconceivable that the knowledge-based talents lack political perception, as political perception have a close relationship with behaviors. The stagnation and decline of national development will be irreversible if the overall values of a country's knowledge-based talents are incompatible with the prevailing values. Therefore, properly guiding the value of knowledge-based talents should be the top priority in exploring the knowledge-based talents under many circumstances.

The cultivation of emotional political identity and behavioral political identity of the knowledge-based talents should be carried out simultaneously. From the perspective of knowledge transformation, under the current circumstances, emotional political identity can promote knowledge internalization, and behavioral political identity can promote knowledge integration, thus jointly promote the growth of psychological intelligence. Emotional political identity is embodied in values and world views and belongs to the category of ideology, while behavioral political identity is embodied in daily work and learning, and belongs to the category of organizational behavior. The former can be inspired by ideas and ideas, while the latter can be inspired by regulations and institutions. For most of our knowledge-based organizations in China, this is a new challenge.

Reinforce knowledge management and make full use of various knowledge tools to enhance knowledge transfer. In the knowledge society, the knowledge-based talents are an important carrier of knowledge capital. Therefore, knowledge management and the knowledge-based talents exploration are two aspects of the same problem. At present, knowledge management has achieved a lot, but unfortunately, these results have not been organic integration with the exploration of the knowledge-based talents research. Knowledge transformation is only one of the many methods of knowledge management, which has a significant effect on the growth of Psychological Intelligence of knowledge-based talents. It also shows that knowledge management methods play an important role in the exploration of knowledge-based talents.

Although this study has tested the relationship among political identity, knowledge transformation and psychological intelligence of the knowledge-based talents. However, it does prove the existence of this correlation effect, but it does not mean that this correlation effect has already produced a substantial role in the real economy and management. On the contrary, the degree of political identity of the knowledge-based talents in China is low, and there is no positive sign for the knowledge-based talents on the present political system in terms of emotion and behavior, which holds back the growth of psychology intelligence and definitely need the ruling party to think about it.

\section{REFERENCES}

[1] Zhang H. An Ideological Perspective Analysis of Political Identity in Contemporary China [J].,2018(7):28-33

[2] Alice E W. J. Lacey, Centripetal democracy: democratic legitimacy and political identity in Belgium, Switzerland, and the European Union[J].Acta politica,2018,56(4):994-995.

[3] Mayer A, Shelley, Tara O'Connor. The dual importance of political identity in environmental governance: the case of oil and gas policy in Colorado[J].Society \& natural resources,2018,31(11):1230-1247.

[4] Brown L, Arriaza Ibarra K. Commemoration and the expression of political identity[J].Tourism management,2018,68:79-88.

[5] Khoo S M. Sustainable knowledge transformation in and through higher education: a case for disciplinary leadership[J].International journal of development education \& global learning,2017,8(3):5-24.

[6] Pateli A, Lioukas S. How functional involvement affects the transformation of external knowledge into innovation outcomes[J].R\&D management,2019,49(2):224-238.

[7] Tang H, Wang S. Civil duty, gratitude and political identity [J]. Nanjing Social Sciences,2016(12):65-70.

[8] Buschman, John. Between neoliberalism and identity politics: academic librarianship, democracy and November 8, 2016[J].The journal of academic librarianship, 2018,44(2):287-294

[9] Lian Q. Political Identity of Non-Party Intellectuals in the New Period under the Value Identity [J].Journal of Central Socialist College, 2016(2):48-52.

[10] Nonaka, Ikujiro. The knowledge-creating Company [J]. Harvard Business Review, 1995,(6):96-105.

[11] Nonaka I, Toyama R, Konno N. SECI, ba and Leadership: A unified model of dynamic knowledge creation [J]. Range planning, 2000 (33):5-34

[12] Polanyi M. The logic of tacit inference [J]. Philosophy, 1966 (41):1-18.

[13] Sternberg,R,J. A threefold model of intellectual style[J]. Educational Psychology Review,2005,17(1):1-53.

[14] Sternberg,R.J A broad view of intelligence[J]. Consulting Psychology Journal Practice and Research,2003,55(3):139-152.

[15] Hang T, Yang T, Wang Z. A Study on the Relevance of Political Identity, Psychological Contract and Successful Intelligence: A Data Test Based on Knowledge Talents [J]. Economic Management in East China,2014,28(6):112-117.

[16] Subject Group of Wuhan Socialist College. Investigation and Analysis of Ideological Status and Political Identity of Non-Party Intellectuals in Wuhan [J].Journal of Hubei Socialist College, 2017(2):42-48. 
[17] Panana, Ren Chengjin. Challenges and Solutions to Political Identity of Non-Party Intellectuals in the New Era [J].,2018(7):23-25.

[18] Zeng N. Modern Promotion of Political Identity: Based on the Dimension of National State Construction [J]. Journal of Zhongnan University (Social Science Edition),2017,23(2):127-133.

[19] Megna P. Existentialist medievalism and emotional identity politics in simone de beauvoir's the useless mouths[J].Exemplaria,2018,30(3):241-256.

[20] Wieser, Clemens. Teaching and personal educational knowledge-conceptual considerations for research on knowledge transformation[J]. European journal of teacher education, 2016,39(5):588-601.

[21] Fernández, Lilia. Race baiting, identity politics, and the impact of the conservative economic agenda on Latinos/as[J].Latino studies, 2018,16(4):524-530.

[22] Zeng N.. An Investigation on the Formation of Political Identity in the Change of Cultural Situations [J]. Journal of Beijing University of Technology (Social Science Edition),2017,19(5):156-161.

[23] Tippmann E, Scott P S, Parker A. Boundary capabilities in MNCs: knowledge transformation for creative solution development[J].Journal of management studies,2016,54(4):455-482.

[24] Zhou A, Chen Y. and Zhai R.. Innovation Openness and Knowledge Transfer in Enterprises: A Study Based on Data of Innovative Enterprises in China [J].China Science and Technology Forum,2017(12):91-96.

[25] Yue H. Key Influencing Factors of Social Science Knowledge Conversion and Utilization [J]. China Science and Technology Forum,2019(7):181-188.

[26] Fang Gang, Gu Lili. Research on Knowledge Transfer Behavior of Industry-University-Research Collaborative Innovation Based on SECI Expansion Model [J].Soft Science,2019(6):24-29.

[27] Karpinski R I, Kolb A M K, Tetreault N A, et al. High intelligence: a risk factor for psychological and physiological over excitabilities[J].Intelligence,2018,66:8-23.

[28] Sulianti A, Lubis F S, Az-Zahra F, et al. Can emotional intelligence restrain excess celebrity worship in bio-psychological perspective?[J].IOP conference series materials science and engineering,2018,434(1):14-22. 